\title{
Mao and Giap on Partisan Warfare
}

\author{
Balázs FORGÁCS ${ }^{1}$
}

\begin{abstract}
According to Liddell Hart: "He [Mao] progressively developed his guerrillas into regular forces, while exploiting a combination of the two forms of warfare." [1: 363] Mao Tse-tung is considered to be one of the most determinative of all guerrilla warfare $^{2}$ theoreticians, whose works and ideas in the field of military science had a great impact on irregular warfare during the Cold War and they still continue to do so nowadays. One of the most famous followers of the Chinese revolutionary was Vo Nguyen Giap, under whose military leadership the Vietnamese defeated both the French and the Americans. Based on primary resources, this essay summarises the most significant ideas on guerrilla/partisan warfare by the two military theoreticians. This essay was supported by the János Bolyai Research Scholarship of the Hungarian Academy of Sciences.
\end{abstract}

Keywords: Mao Tse-tung, Vo Nguyen Giap, guerrilla warfare

\section{Introduction}

The evolution of guerrilla warfare theories is characterised by the take over and adaption to the local circumstances of the theoretical-but practical experience based-works of other theoreticians. Mao Tse-tung and Vo Nguyen Giap played central roles in the development of guerrilla warfare theories: after taking over the ideas from $19^{\text {th }}$ [2] and early $20^{\text {th }}$ century classics, [3] they adapted and improved them according to the circumstances of the Chinese Civil War and the fighting taking place in Indochina. Their works provided a model for insurgencies in the later part of the $20^{\text {th }}$ century, but their impact can also be felt even today.

At the turn of the century, the question arose whether guerrilla forces are able to achieve victory alone against regular forces. Fighting on the Arabian Peninsula highlighted the fact that irregular forces are only able to achieve complete victory when complemented by regular units. However, what can one do if there are no such units available? The answer to this question was provided by Chinese communist leader Mao Tse-tung. Vo Nguyen Giap was both a theoretical and a practical follower of Mao and in his own works of military science, he underlined the significance of indirect ways, especially that of the national and international propaganda next to military operations.

\footnotetext{
1 Army Major, Ph.D., National University of Public Service, Faculty of Military Sciences and Officer Training, Department of Military Strategy and Military Theory; e-mail: forgacs.balazs@uni-nke.hu; ORCID ID: 00000001-5795-3281

2 In this work, the terms guerrilla and partisan are used as synonyms.
} 


\section{Mao on Guerrilla Warfare}

One of the most significant military and political theoretician of guerrilla warfare was Mao Tse-tung. In summarising his experiences from the civil war against the Koumintang from 1927, and from the fight against the Japanese during the Second World War, he highlighted that without the cooperation of the regular units of the Chinese Red Army and the partisan forces, war could not be fought successfully. According to the own poetic words of the Chinese party leader "Considering the revolutionary war as a whole, the operations of the people's guerrillas and those of the main forces of the Red Army complement each other like a man's right arm and left arm, and if we had only the main forces of the Red Army without the people's guerrillas, we would be like a warrior with only one arm.” [4] He thought that in the war against Japan, the Chinese regular units were to play the decisive role, but the supplementary role of partisan forces was also indispensable for a successful fight. Mao saw it correctly that the struggle against the Japanese was to last for a long time, since the Chinese first had to train those armed forces, which can later successfully engage the foreign invaders. This prolonged war favoured the Chinese, who prepared thoroughly for the counterattack at their base areas.

As far as the relationship between military and the political leadership is concerned, Mao clearly stated the subordinate role of the military in achieving the political aims. The leading role of politics was drawn up in the political objectives, which had to be clearly and precisely communicated to the people, and among them the members of the military, as well.

The head of the Chinese communists further underlined that it was especially important for the officers of the armed forces to study political guidelines. This way, they may understand the connection between politics and the military, or in other words, they comprehend that military operations are used to achieve political aims. [5]

From the works of Mao, it becomes clear that he took many ideas from the classics of Marxism-Leninism, especially from the works of Lenin. In his work on partisan warfare, he quotes the thoughts of the Russian revolutionary many times, whose works in turn were significantly influenced by Carl von Clausewitz and his epic On War. Thus, it may be assumed that the works of Lenin played an important role and acted as a bridge between the Chinese communist and the main work of Clausewitz. Based on quotations taken from the Prussian theoretician [5] [6] it is fair to say that Mao-as a follower of Lenin-accepted the idea of Clausewitz that politics determines military affairs. Popular uprising got its own separate chapter in the work of Clausewitz, which might have been known by Mao, too. However, he could only identify himself with the Clausewitzian theory on popular uprising partially, as Clausewitz thought that such warfare was only possible under the guidance and leadership of the emperor, and that its aim was to fight against the invaders, and not for a new social order as propagated by the communists.

The role of political control can be found in the sections about organising partisan troops as well: the military commanders of Chinese insurgent units were accompanied by political commissioners, who represented the lowest rank of political control. [5] On the unit commander level, next to the leading military commander, political commissioners were also appointed, in whose subordination worked officials responsible for organising propaganda matters and mass demonstrations. Party leaders ordered the setup of committees in partisan areas of responsibility, in which the representatives of both the political and the military side 
worked together. The delegates of the party were responsible for the political and ideological work on a unit level, as well. In an indirect manner, they aided the achievement of war goals with their political work among the troops, the populace and even the enemy, since [5] "clearly then the protracted revolutionary struggle in the revolutionary base areas consists mainly in peasant guerrilla warfare led by the Chinese Communist Party”. [7]

Mao divided wars of national liberation into three phases, which classification he took over from Marx [8] and developed. The first phase is characterised by strategic offence of the enemy, and strategic defence by the Chinese; in the second phase the enemy settles into strategic defence, while the Chinese prepare for strategic offence; the third phase is the time for the Chinese strategic counterattack and strategic withdrawal for the enemy. Partisan forces take part in all three phases. In the first and in the final phases, they act as auxiliaries for the regular units, but their fighting is the most important during the second phase, when - operating in the rear of the enemy - they constantly attrite the Japanese forces. [6] Partisan forces also develop during the fighting, and as Mao said: "In saying this we also have in mind the strategic task of developing guerrilla warfare into mobile warfare." [6] "It is also beyond doubt that in the long course of struggle the guerrilla units and guerrilla warfare will not remain as they are but will develop to a higher stage and evolve gradually into regular units and regular warfare.” [9] This change in applying violence can be found in other thoughts of Mao too, which were also highlighted by Liddell Hart: "Mao step by step converted his guerrilla troops into a regular army, while also being able to join the two ways of warfare.” [1: 363]

According to Mao, irregular warfare had many advantages in the war against the Japanese: it shrank the area occupied by the enemy and in parallel widened the base areas of their own regular units; it disencumbered the regular fighting forces; provided troop replenishment for the army; helped the populace in the rear of the enemy and with this it expanded the influence of the Chinese Communist Party in parallel; lowered the moral of the Japanese and at the same time raised the moral of the Chinese. [9]

Mao summed up the strategic programme of partisan warfare as follows: "(1) the use of initiative, flexibility and planning in conducting offensives within the defensive, battles of quick decision within protracted war, and exterior-line operations within interior-line operations; (2) co-ordination with regular warfare; (3) establishment of base areas; (4) the strategic defensive and the strategic offensive; (5) the development of guerrilla warfare into mobile warfare; and (6) correct relationship of command." [10] According to him, partisan warfare is a very unique kind of belligerency: "Generally speaking, mobile warfare performs the task of annihilation, positional warfare performs the task of attrition, and guerrilla warfare performs both simultaneously.” [6]

Along with the regular units, the struggle of the partisan was also aided by the populace. Furthermore, without their support, the irregular warfare of the partisan becomes impossible in the rear areas of the enemy. For this reason, it is particularly vital to gain and maintain the kindliness and support of the populace. As Mao explained with a metaphor: "Many people think it impossible for guerrillas to exist for long in the enemy's rear. Such a belief reveals lack of comprehension of the relationship that should exist between the people and the troops. The former may be likened to water the latter to the fish who inhabit it. How may it be said that these two cannot exist together? It is only undisciplined troops who make the people their enemies and who, like the fish out of its native element cannot live.” [5] 
When communicating with the people, clarity and brevity were the greatest advantage of Mao over his rivals. His metaphors, short examples and thoughts broken down into clear points were effective in communicating his message to every layer of society, especially to the lower classes, those the communists relied on mostly as their demographic basis. He greatly appreciated the role of propaganda: he prescribed that every bigger partisan unit shall have a mimeograph, and should print newspapers and leaflets to ensure that the population is informed and to also gain their support. [5]

The Three Main Rules of Discipline and the Eight Points for Attention was aimed at persuading them, and also served as a sort of "ethical codex" to prepare the staff of the Chinese Red Army, later renamed the Chinese People's Liberation Army (PLA). As early as 1928 — right after the fighting broke out-Mao already published his directive in three points on how to deal with the populace: “(1) Obey orders in your actions; (2) Don’t take anything from the workers and peasants; and (3) Turn in all things taken from local bullies.” [11]

He further supplemented these rules with six more remarks in the summer of the same year. These were: “(1) Put back the doors you have taken down for bed-boards; (2) Put back the straw you have used for bedding; (3) Speak politely; (4) Pay fairly for what you buy; (5) Return everything you borrow; and (6) Pay for anything you damage.” [11] After 1929, Mao changed some of those points. The second rule was replaced by "Don't take a single needle or piece of thread from the masses!”, while the third one changed two times: first to "Turn in all money raised!”, which was later made more specific by “Turn in everything captured!”. The already existing six points were also expanded by two more: "Don’t bathe within sight of women” and “Don’t search the pockets of captives”. Finally, on 10 October 1947, he sent the document below to the General Headquarters of the Chinese People's Liberation Army:

“1. Our Army’s Three Main Rules of Discipline and Eight Points for Attention have been practiced for many years, but their contents vary slightly in army units in different areas. They have now been unified and are hereby reissued. It is expected that you will take this version as the standard one for thorough education and strict enforcement. As to other matters needing attention, the high command of the armed forces in different areas may lay down additional points in accordance with specific conditions and order their enforcement.

2. The Three Main Rules of Discipline are as follows:

(1) Obey orders in all your actions.

(2) Don’t take a single needle or piece of thread from the masses.

(3) Turn in everything captured.

3. The Eight Points for Attention are as follows:
(1) Speak politely.
(2) Pay fairly for what you buy.
(3) Return everything you borrow.
(4) Pay for anything you damage.
(5) Don't hit or swear at people.
(6) Don't damage crops.
(7) Don't take liberties with women.
(8) Don’t ill-treat captives.” [11] 
Mao also modified the relationship between popular support and the partisans: while Marx, Engels and Lenin all thought that the poverty-stricken proletarian of the cities is going to form the popular basis of the revolutionary struggle, in China it was the populace of the countryside - the peasantry — which provided manpower for the partisans. The explanation is to be found in the different societal structures: In the less industrialised China-compared to Europe-there were only a few factories and consequently a much smaller number of industrial workers, while the number of the peasantry in the countryside proved perfectly sufficient for growing the number of partisan units.

Mao also defined the term base area: "What, then, are these base areas? They are the strategic bases on which the guerrilla forces rely in performing their strategic tasks and achieving the object of preserving and expanding themselves and destroying and driving out the enemy. Without such strategic bases, there will be nothing to depend on in carrying out any of our strategic tasks or achieving the aim of the war.” [10] He highlighted that these were to be defended at all costs, since these lands are the showpiece examples of the new social order, and their defence provides the supporting background via which the guerrilla troops can become regular units. These difficult to access, well camouflaged, well protected-if required - and preferably as large as possible base areas served not only as starting points of offensives, but they were also the place where new units were organised, the troops rested and secured their resupply. [12] [13]

\section{General Giap on Guerrilla Warfare}

Vietnam fought for its independence for close to three decades, first against the French and later against the Americans. This struggle against the invaders was spearheaded by the leadership of the Vietnamese Communist Party—headed by Ho Chi Minh—who enjoyed the superpower support of both the Soviet Union and China. It was General Vo Nguyen Giap, the commander of the Vietnamese armed forces who analysed the Vietnamese conflict from a military scientific and theoretical point of view, while also propagating the military victories. As a follower of Mao, he applied his experiences of the Chinese Civil War and the theories of left-wing theoreticians to the Vietnamese circumstances.

According to the Vietnamese general, the war of national liberation-due to its nature, and according to the Marxist theory - was a just war. While as far as the opposing forces were concerned-in modern terms - it was also an asymmetric conflict. In his most important works of military theory, Giap took over [14] [15] many ideas of the Maoist theory: [16: 43] the armed forces, which are subordinate to the political leadership of the party must win in a protracted conflict, since in such a prolonged war, one cannot only count on the weakening of the enemy, but also on its tiring, because the armed forces of the enemy are prepared for a fast, high intensity conflict. [14: 53-54] [15: 112-113] The Vietnamese general defined guerrilla warfare as: "Guerrilla warfare is the form of fighting of the masses of people, of the people of a weak and badly equipped country who stand up against an aggressive army which possesses better equipment and technique. This is the way of fighting the revolutionary war which relies on the heroic spirit to triumph over modern weapons, avoiding the enemy when he is the stronger and attacking him when he is the weaker, now scattering, now regrouping one’s forces, now wearing out, now exterminating 
the enemy, determined to fight him everywhere, so that wherever the enemy goes he would be submerged in a sea of armed people who hit back at him, thus undermining his spirit and exhausting his forces.” [15: 118-119] His popular support-due to the same economic reasons as in China-came from the peasantry of the countryside.

Similarly to Mao, Giap also took over from Marx the three phases of war: the first being the struggle in defence, the second being the time of balance, while the third the phase of counteroffensive. [15: 114-115] He dedicated a key role for the guerrillas in all three phases, but their role was the most significant in the first phase, as their activities provided the preconditions of the next two phases. The Vietnamese armed forces, formed under the command of Giap may be categorised into the following categories: "para-military organisations or guerrilla units, regional troops and regular units.” [14: 60] The Vietnamese general considered the guerrilla forces to be the core of the revolutionary armed forces: these units launch the armed struggle, from which the two other categories of units develop later. According to him, war has to be conducted with the combined application of all these levels, but only regular units can decisively defeat the enemy.

He stressed that one of the key prerequisites of winning the war is the development of mobile warfare next to the guerrilla war. "Mobile warfare is the fighting way of, concentrated troops, of the regular army in which relatively big forces are regrouped and operating on a relatively vast battlefield, attacking the enemy where he is relatively exposed with a view to annihilating enemy manpower, advancing very deeply then withdrawing very swiftly, possessing to the extreme, dynamism, initiative, mobility and rapidity of decision in face of new situations”, [15: 120-121] but this assumes the creation of regular units. He wrote on the process of these that: "People’s war, long term war, guerrilla warfare developing step by step into mobile warfare, such are the most valuable lessons of the war of liberation in Viet Nam.” [14: 57-58] The fall/liberation of Dien Bien Phu [17] confirmed the theory of Giap “[i]n general, our Resistance War was a guerrilla war moving gradually to regular war, from guerrilla warfare to mobile warfare combined with partial entrenched camp warfare”. [15: 117] However, he also underlined that "it is necessary to develop guerrilla warfare into mobile warfare does not mean brushing aside guerrilla warfare, but that in the widely extended guerrilla activities, the units of the regular army gradually grew up and were able to wage mobile warfare and side by side with that main force there must always be numerous guerrilla troops and guerrilla activities". [15: 122-123] "From the strategic point of view, guerrilla warfare, causing many difficulties and losses to the enemy, wears him out.” [15: 120] In summary of the above, it can be said that in the theory of Giap, guerrilla warfare naturally stayed as one of the forms of fighting, but its role in the last phase of war took an auxiliary role, as for the destruction of the enemy, a gradual transition among the revolutionary troops must occur towards mobile warfare. Next to indirect warfare, this shows the emergence and strengthening of direct warfare in the last phase.

Giap dedicated great roles to indirect tools next to the direct ways of employing strength, since "political activities were more important than military activities, and fighting less important than propaganda”. [15: 89] About the role of national propaganda, he stressed that it has to be led by the party, and executed mostly by the national armed forces. The popular basis of the army can be setup with this, while also disrupting the enemy at the same time. The army setup in such a manner, is going to have a good relationship with the populace, as the same goals and the same enemy melts them into one. The fighting army also educates, 
teaches and helps the people, who are giving the greatest support in exchange, all in order to achieve the joint goals. [14: 65] [15: 89] Propaganda however, should not only include big and rousing words: according to Giap, the party-lead nation building on communist-held areas is also providing huge moral support for the revolutionary war effort. [15: 116-117] While propaganda executed on the international scene is able to influence the world, and with it, even the public opinion of the enemy: war events broadcast by the media may turn the population of the enemy away from supporting the war, and as such impact the enemy negatively in an indirect manner.

\section{Conclusion}

The theory of guerrilla warfare was formed by historical experiences and local conditions. The works of Mao Tse-tung and Vo Nguyen Giap illustrate this process beautifully, as both theoreticians used the ideas of their forerunners, as well as the social, geographical and political peculiarities of their respective battlefields for formulating their own theories on guerrilla warfare. The theories of Mao and Giap highlighted the fact that, although no armed struggle can be started without the guerrillas, their role is not exclusive anymore, since without organising regular units, the strategic goals cannot be achieved. As a consequence of their contribution, such terms have become part of the theory on guerrilla warfare as: protracted war and its three stages, evolution of partisans into regular units, the importance of national and international support, the requirement of forming base areas, and the usage of national and international propaganda as an indirect tool. Their life-work can be identified both in South-American and African uprisings, as well as in irregular struggles fought by non-state actors nowadays. [18] [19]

\section{References}

[1] LIDDELL HART, B. H.: Strategy. The Indirect Approach. London, Faber and Faber Ltd., 1967.

[2] FORGÁCS B.: A néppel az uralkodóért. Az első gerillaelméletek. [With People for the Monarch. The First Theories of Guerrilla Warfare.] Felderító Szemle, 151 (2016), 21-57.

[3] FORGÁCS B.: A néppel a népért - korai baloldali partizánelméletek (Marx, Engels és Lenin a forradalmi háborúról). [With People for People - Early Leftist Partisan Theories (Marx, Engels and Lenin on the Revolutionary War.)] Hadtudomány, 282 (2018), 41-55. DOI: https://doi.org/10.17047/HADTUD.2018.28.2.41

[4] MAO Tse-tung: Problems of Strategy in China's Revolutionary War. www.marxists.org/ reference/archive/mao/selected-works/volume-1/mswv1_12.htm (Downloaded: 31.01.2019)

[5] MAO Tse-tung: On Guerrilla Warfare. www.marxists.org/reference/archive/mao/ works/1937/guerrilla-warfare/index.htm (Downloaded: 31.01.2019)

[6] MAO Tse-tung: On Protracted War. www.marxists.org/reference/archive/mao/selectedworks/volume-2/mswv2_09.htm (Downloaded: 31.01.2019) 
[7] MAO Tse-tung: The Chinese Revolution and the Chinese Communist Party. www.marxists. org/reference/archive/mao/selected-works/volume-2/mswv2_23.htm (Downloaded: 31.01.2019)

[8] MARX, K.: Revolutionary Spain. www.marxists.org/archive/marx/works/1854/ revolutionary-spain/index.htm (Downloaded: 06.02.2019)

[9] MAO Tse-tung: Problems of War and Strategy. www.marxists.org/reference/archive/mao/ selected-works/volume-2/mswv2_12.htm (Downloaded: 31.01.2019)

[10] MAO Tse Tung: Problems of Strategy in Guerrilla War against Japan. www.marxists.org/ reference/archive/mao/selected-works/volume-2/mswv2_08.htm (Downloaded: 31.01.2019)

[11] MAO Tse-tung: On the Reissue of the Three Main Rules of Discipline and the Eight Points for Attention - Instruction of the General Headquarters of the Chinese People's Liberation Army. www.marxists.org/reference/archive/mao/selected-works/volume-4/mswv4_23.htm (Downloaded: 31.01.2019)

[12] MAO Tse-tung: Why Is It that Red Political Power Can Exist in China? www.marxists.org/ reference/archive/mao/selected-works/volume-1/mswv1_3.htm (Downloaded: 31.01.2019)

[13] MAO Tse-tung: The Struggle in the Chingkang Mountains. www.marxists.org/reference/ archive/mao/selected-works/volume-1/mswv1_4.htm (Downloaded: 31.01.2019)

[14] GIAP, V. N.: People’s War People’s Army. In. GIAP, V. N.: People’s War People's Army. Hanoi, Foreign Languages Publishing House, 1974. 41-74.

[15] GIAP, V. N.: The Great Experiences Gained by Our Party in Leading the Armed Struggle and Building Revolutionary Armed Forces. In. GIAP, V. N.: People's War People's Army. Hanoi, Foreign Languages Publishing House, 1974. 75-169.

[16] SCHMITT, C.: The Theory of the Partisan. A Commentary/Remark on the Concept of the Political. www.unqualified-reservations.org/archive/carlschmitttheoryofthepartisan.pdf (Downloaded: 06.02.2019)

[17] GIAP, V. N.: Dien Bien Phu. In. GIAP, V. N.: People's War People’s Army. Hanoi, Foreign Languages Publishing House, 1961. 17-32. www.marxists.org/archive/giap/1961-pwpa.pdf (Downloaded: 06.02.2019)

[18] FARKAS S.: Az ISIL alkalmazott eljárásai és stratégiája. [Procedures and Strategy Applied by ISIL.] Hadtudományi Szemle, 1462 (2018), 3-15.

[19] FARKAS S.: A földrajzi és a társadalmi tér megszerzéséért folytatott küzdelem. Az ISIL hadviselése Mao Ce-tung tanainak tükrében. [The Fight for Geographic and Social Spaces. The Warfare of ISIL in Light of Mao Zedong’s Teachings.] Honvédségi Szemle, 1461 (2018), 12-25. 